\title{
HISPANO-AMERICANOS EM SÃO PAULO
}

\section{Alcances e Limites de um Processo de Integração}

\author{
Sidney Antonio da Silva*
}

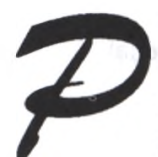
ropomo-nos analisar neste artigo alguns aspectos da reprodução social dos hispano-americanos em São Paulo, buscando traçar, em primeiro lugar, um possível perfil destes imigrantes na cidade, com 0 objetivo de destacar as diferenças e as semelhanças presentes em cada grupo. Em segundo lugar, focalizaremos as formas como cada grupo se insere no mercado de trabalho paulistano, mostrando as suas peculiaridades e contradições. Finalmente, analisaremos alguns aspectos da sua integração sócio-cultural, a qual antecede e extrapola os limites do tratado que formalizou o Mercosul, focalizando questões complexas atinentes aos conceitos de "cidadania transnacional" e de identidades.

Os dados aqui analisados foram colhidos no arquivo do Centro Pastoral dos Latino-americanos, situado nas dependências da Igreja N. Sra. da Paz, no bairro da Liberdade-SP. Foram consultadas $1402 \mathrm{fi}$ chas relativas à decada de 90 . Vale ressaltar que o referido arquivo apresenta vários problemas, pois o preenchimento dos campos em boa parte das fichas é bastante deficiente, e muitas vezes a informação não é clara, sendo passivel de várias interpretações. Apesar desses problemas, tais dados apresentam uma grande riqueza, pois no verso da maioria das fichas há informações sobre a trajetória do imigrante, a partir do momento em que ele se apresentou à Pastoral para encaminhar o seu processo de documentação ou pedir alguma forma de ajuda.

Entre os grupos de imigrantes atendidos pelo referido Centro de Pastoral, destacamos os bolivianos, os chilenos, os argentinos, os paraguaios, os uruguaios e os peruanos. No caso boliviano vale notar, entretanto, que os dados foram colhidos a partir de 1994, pois os que se referem aos anos anteriores, já foram analisados em outro trabalho pelo autor deste artigo (Silva, 1997). Tais dados serão, portanto, comparados com os colhidos ultimamente. Dentre os dados auferidos e que nos possibilitam construir um possivel perfil dos hispano-americanos em São Paulo, apresentamos a classificação por sexo, idade, estado civil, grau de instrução, proveniência, ocupação profissional, local de residência em São Paulo, filho brasileiro e a passagem por uma das instituições que acolhe os migrantes na cidade, a AVIM (Associação de Voluntários pela Integração dos Migrantes).

\section{COMPOSIC̣ÃO DO FLUXO MIGRATÓRIO HISPANO-AMERICANO EM SÃO PAULO}

\section{Bolivianos}

No caso boliviano foram consultadas 334 fichas, as quais nos possibilitam formar um quadro sobre a composição do grupo na cidade. Em relação ao sexo temos um ligeiro predomínio dos homens sobre as mulheres, ou seja, $55,1 \%$ e $44,9 \%$ respectivamente. As faixas etárias indicam, por sua vez, que o grupo apresenta uma população jovem, pois a maioria destes imigrantes enquadra-se numa faixa etária entre 18 e 44 anos, ou seja, na melhor fase produtiva de suas vidas. Já em relação ao estado civil os dados sugerem o inverso, ou seja, o predomínio dos casa- dos sobre os solteiros, se considerarmos esses últimos como se não fossem solteiros, uma vez que convivem sem papel passado.

Comparando estes dados com os colhidos em nossa pesquisa anterior, podemos concluir que houve uma significativa mudança na composição do grupo em relação ao sexo, posto que o dado anterior apontava para uma maioria expressiva do sexo masculino, 74,2\% (Silva, 1997:91), enquanto os dados atuais apontam para uma diminuição da diferença entre homens e mulheres. Outro dado que chama a atenção é o pequeno número de imigrantes abaixo de 18 anos de idade. Isto se deve a duas razões: A primeira, porque muitos destes jovens escondem a sua idade real, dizendo ter pelo menos 18 anos, pois empregar menores traz sérios problemas aos seus empregadores. Em segundo, porque estes menores não se apresentam ao Centro de Pastoral para regularizar a sua situação de indocumentação, uma vez que a única possibilidade existente seria se algum estrangeiro em situação regular aceitasse ser o seu tutor.

Com relação ao grau de instrução, esse foi o dado mais deficiente desta amostra, pois apenas 39 registros apresentaram esta informação, o que torna complicado tecer qualquer consideração sobre o mesmo. Na minha pesquisa anterior constatei que o grupo apresentava um nível de escolaridade médio entre os homens, ou seja, com o primeiro grau completo, ou pelo menos parte do segundo. Porém, entre as mulheres, o nível é um pouco menor (Silva, op.cit., p.92).

No que diz respeito à ocupação profissional, grande parte deles continua no 
ramo da costura, $44,0 \%$, ou seja, com um percentual semelhante ao constatado anteriormente, $48,0 \%$. No entanto, outras profissões também aparecem com frequência, como a de comerciante, médico, engenheiro, dentista, advogado, eletricista, mecânico, marceneiro, artesão, serviço doméstico, pedreiro, entre outras.

Da mesma forma, o local de residência continua sem grandes alterações, ou seja, grande parte deles reside e trabalha nos bairros centrais da cidade, como Brás, Bom retiro, Pari, Cambuci, Campos Elísios, Liberdade, entre outros. Constata-se, porém, uma sensível mudança das oficinas de costura para bairros mais distantes, em razão do alto custo do aluguel na zona central. Entre os Bairros que mais aparecem temos: Guaianazes, Itaquera, Vila Maria, Vila Guilherme, Jardim Brasil, Edu Chaves, Engenheiro Goulart. Pirituba, São Miguel, entre outros.

Outro dado que merece uma particular atenção é o alto número de casais que tiveram um outro filho no Brasil, atingin- do $38,9 \%$ do total dos registros consultados. Isto pode estar indicando que ter um outro filho passou a ser uma estratégia para conseguir a documentação permanente no pais, uma vez que a lei dos estrangeiros se fundamenta no princípio do "jus soli". Para ilustrar este argumento vale ressaltar o caso de uma família que já tendo 7 filhos bolivianos, acabou tendo também um filho brasileiro. Entretanto, o percentual de pessoas casadas ou que convivem com brasileiros é de apenas $7,1 \%$.

Da mesma forma temos um baixíssimo número de pessoas que passaram pelo albergue (AVIM), 4,5\% do total da amostra. Tal dado indica a solidez das redes sociais entre esses imigrantes, pois ao chegarem na cidade eles já contam com uma proposta de emprego e moradia entre os parentes ou compatriotas, com os quais assumem um compromisso de "fidelidade" pelo "favor" concedido. As implicações de tais relações serão analisadas mais adiante.

\section{Paraguaios}

Outro grupo que apresenta dados semelhantes aos dos bolivianos são os paraguaios, como veremos a seguir. Foram consultadas 107 fichas cujos dados apresentados nos registros foram os mais incompletos entre os grupos analisados. No entanto, é possível tecer algumas considerações. Em relação à composição por sexo temos um percentual de $57,9 \%$ para os homens e $42,1 \%$ para as mulheres. A estrutura etária indica um predomínio dos jovens, ou seja, a maioria apresenta idade entre os 18 e 44 anos. Quanto ao estado civil, os dados indicam que $47,0 \%$ são solteiros, porém, se somarmos o percentual dos casados $(34,0 \%)$ com o dos que declararam conviver com algum cônjuge, teríamos um percentual de $50.0 \%$.

No que se refere à origem dos mesmos, estes em grande parte são oriundos de Assunção (capital), seguida por Puerto Caballero, Concepción, Ponta Porã, Caaguazú, entre outras. O grau escolar é de nível médio e a ocupação profissional

Foto Sidney A da Silva

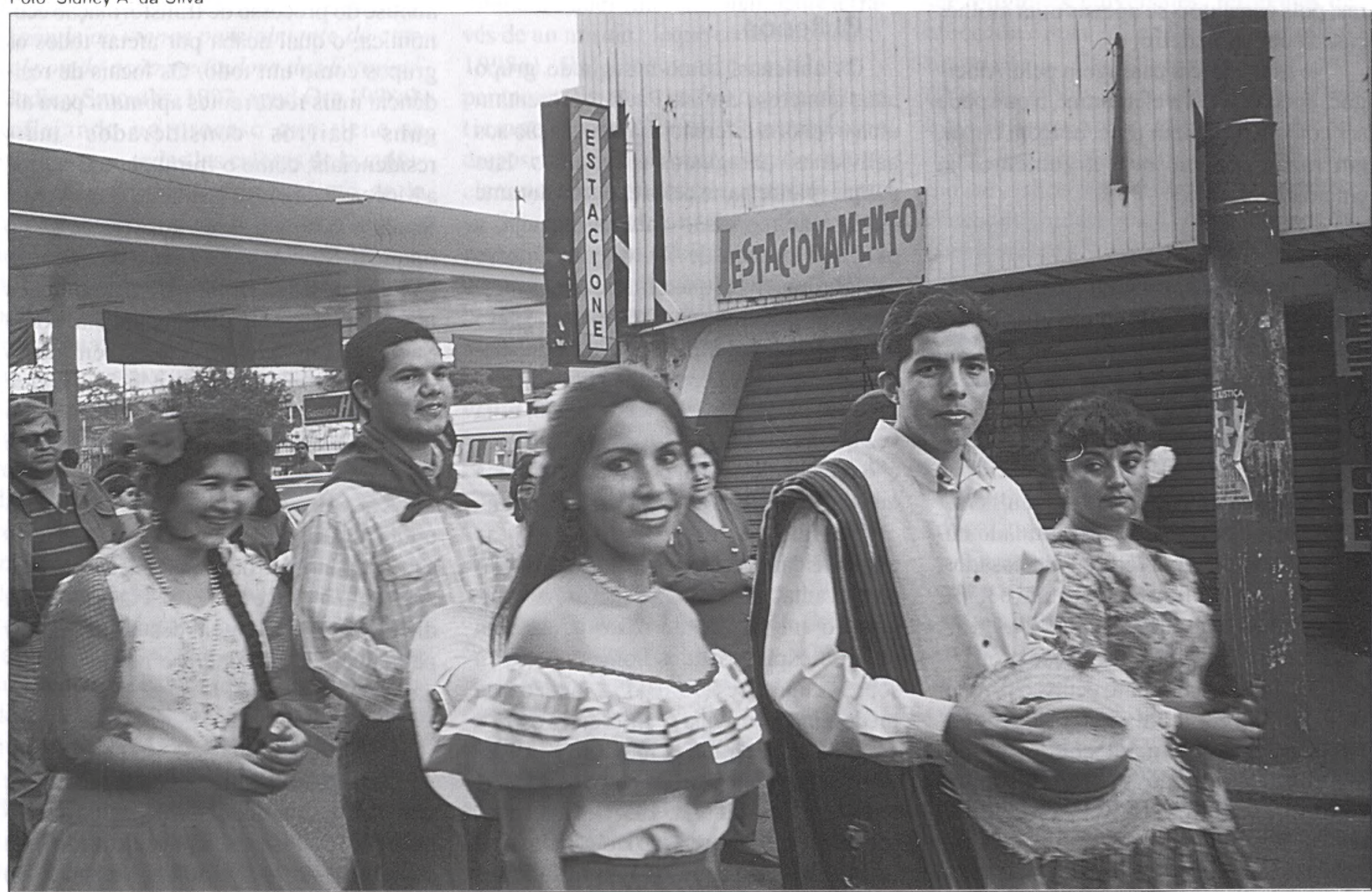

Hispano-americanos na festa da Virgem de Urkupiña, 1997 
que mais se destaca é a da costura, $19,6 \%$ Além da costura aparecem outras atividades como o comércio, o artesanato, os serviços como mecânica, serviço doméstico, artistas, médicos, entre outras. O local de residência de grande parte deles também se concentra nos bairros centrais da cidade como o Brás, o Pari, Santa Cecília, Moóca, bem como em outros bairros periféricos e cidades do $\mathrm{ABCD}$ paulista.

O número de filhos brasileiros também aparece com destaque, pois atingiu $30,8 \%$ do total, dado que pode estar indicando a mesma estratégia de regularização adotada pelos bolivianos. Por outro lado, pode estar indicando também que novas familias se formaram aqui em São Paulo. conjugando assim o desejo de ter um filho com a necessidade da regularização jurídica. De igual forma o número de pessoas que estão casados ou convivem com brasileiros é significativo, perfazendo $14,9 \%$, praticamente o dobro dos bolivianos. E se olharmos este dado sob a perspectiva de gênero, temos uma maioria absoluta de homens casados com brasileiras, pois constatou-se apenas uma mulher casada com brasileiro.

No que tange à passagem pelo Albergue, apenas $7,4 \%$ a efetuaram, $o$ que pode ser considerado uma porcentagem baixa, em razão dos mesmos argumentos já elucidados acima.

\section{Peruanos}

Os peruanos apresentam alguns dados com significativas diferenças em relação aos dois grupos anteriores. Dos 153 registros consultados foi possível auferir as seguintes especificidades: a primeira é em relação à composição de sexo, apresentando uma acentuada presença masculina, totalizando $68,6 \%$ e $31,4 \%$ de mulheres. A segunda é em relação ao acentuado número de solteiros em relação aos casados, ou seja, os primeiros representam $63,7 \%$, enquanto os segundos atingem $26,7 \%$. A terceira é em relação à ocupação profissional, em que $o$ artesanato ocupa o primeiro lugar. Porém, a faixa etária predominante no grupo coincide com os grupos anteriormente citados, ou seja, a maioria enquadra-se entre os 18 e 44 anos de idade.

Quanto à origem destes imigrantes uma grande maioria apontou a capital Lima como ponto de partida, seguida por Arequipa, Cuzco, Tacna, Puno, Trujillo, entre outras. O grau de escolaridade aponta para um nível médio e a ocupação mais recorrente é a do artesanato incluindo o comércio ambulante, seguida pela costura e pelos serviços, como mecânica, pintura, marcenaria, técnicos de eletrônica. medicina. entre outros. O local de residência mais recorrente também são os bairros centrais da cidade como o Brás, Bom Retiro, Santa Cecília, Cambuci, Bela Vista, e outros como Perdizes, Butantã, Itaim Bibi e Tatuapé

Com relação ao item filho brasileiro a recorrência é bem menor em relação aos bolivianos e paraguaios. $11,0 \%$ do total de registros. Já em relação a passagem pelo albergue o índice é bem maior, ou seja, $26,7 \%$, o que poderia estar indicando uma certa fragilidade das redes sociais no interior do grupo.

A seguir veremos três outros países que integram o denominado Cone Sul: Chile, Argentina e Uruguai.

\section{Chilenos}

Os chilenos, como o segundo grupo mais numeroso em São Paulo, apresentam uma trajetória diferenciada em relação aos bolivianos, paraguaios e peruanos. Isto porque grande parte deles emigrou durante os anos de repressão política, ou seja, a partir da década de 70. Alguns fatores contribuíram para que a inserção dos mesmos fosse diferenciada. O primeiro se deve ao nivel de escolaridade, o qual é superior aos grupos analisados anteriormente. $\mathrm{O}$ segundo se deve ao elemento étnico, uma vez que a maioria deles tem a pele branca e, o terceiro se deve à posição econômica que o Chile ocupa em relação ao Brasil.

Assim sendo, vejamos as especificidades deste grupo através dos dados levantados em 511 registros. A composição em relação ao sexo indica uma maioria expressiva dos homens $(61,0 \%)$ sobre as mulheres $(39,0 \%)$. A faixa etária predominante é a que se situa entre os $18 \mathrm{e}$ 44 anos, apontando, porém, um considerável número de pessoas entre os 45 e 54 anos de idade, ou seja, $13,4 \%$. Já a situação do grupo em relação ao estado civil indica um certo equilíbrio entre solteiros
$(43,8 \%)$ e casados $(39,2 \%)$, mesmo considerando como casados aqueles que declararam conviver com alguma pessoa, o que significa $10,3 \%$.

No que se refere à origem dos chilenos, os dados apontam para uma predominância de Santiago (Capital), seguida por Valparaiso, Antofagasta, Concepción, Arica, Iquique, Viña del Mar, entre outros, conformando, assim, a tendência presente nos grupos anteriores de um processo migratório dentro de cada país, isto é, de um centro urbano menor para um maior, em geral a capital do pais. O nível escolar destes imigrantes enquadra-se em sua maioria dentro de um padrão médio e superior, uma vez que as atividades profissionais mais recorrentes são as relacionadas ao comércio, ao artesanato, aos serviços, como os de mecânica, funilaria, técnicos, médicos, professores, pintores, músicos e outras profissões liberais, como engenheiros, desenhistas, etc. Vale notar, no entanto, que a atividade da costura também aparece, sobretudo nos últimos anos, o que pode ser um indicador importante para a análise do processo de transformação econômica, o qual acaba por afetar todos os grupos como um todo. Os locais de residência mais recorrentes apontam para alguns bairros considerados mais residenciais, como o Ipiranga, o Butantã, a Moóca, Pinheiros, Santana, Casa Verde, Saúde e outros bairros periféricos como Itaquera, São Miguel e Guainazes. Porém, há uma presença significativa de chilenos nos municípios do $A B C D$ paulista, como Santo André, São Bernardo, bem como outros municípios da grande São Paulo, como Barueri, Taboão da Serra, Campo Limpo, Osasco, Guarulhos, Jundiai, entre outros.

A recorrência de um filho brasileiro também é significativa, $23,9 \%$. Em relação ao casamento ou convivência com brasileiros, o índice é de $7,9 \%$. Porém, no que diz respeito à passagem destes imigrantes pelo albergue o número é modesto, apenas $9,5 \%$ dos casos.

\section{Argentinos}

Os argentinos apresentam alguns dados semelhantes aos dos chilenos, como a composição por sexo, apresentando um percentual de $74,2 \%$ de homens e $25,7 \%$

26 - Travessia / Janeiro - Abril / 99 


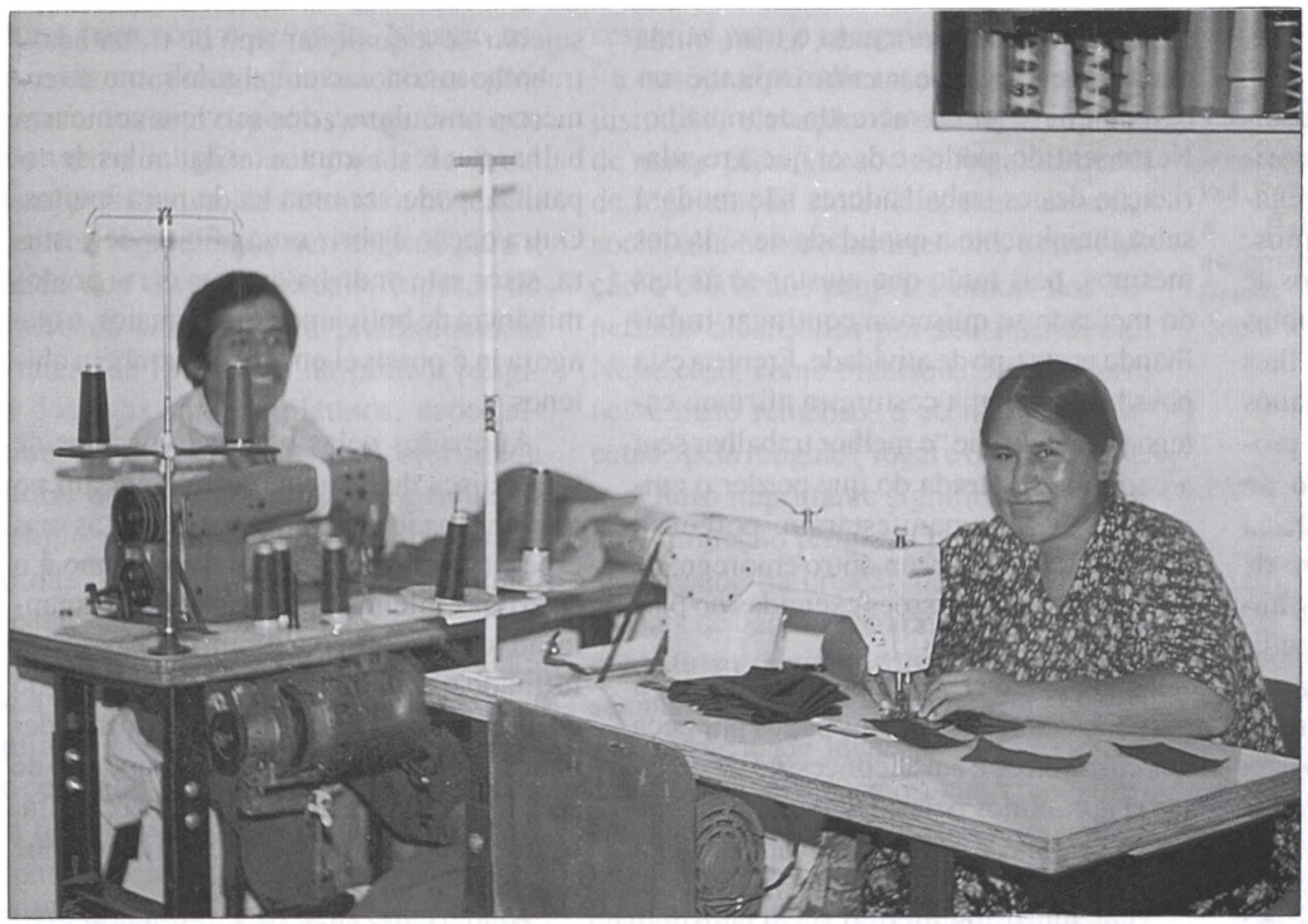

outras. Os dados sobre o nível escolar sugerem que a maioria deles cursou atć o segundo grau, e uma parte a universidade. Os locais de residência mais recorrentes indicados por estes imigrantes foram: os bairros da Moóca, Santa Cecília, Paraiso, Ipiranga, Cerqueira Cesar, Santo Amaro, e municípios vizinhos como o Embú e São Bernardo do Campo. As profissões que mais aparecem são as de carpinteiro, pintor, vendedor, artesão, professor, mecânico, arquiteto e outras atividades relacionadas aos serviços. Vale notar que, embora o grupo como tal não esteja envolvido com a atividade da costura, apareceram, no entanto, três casos. E quanto à passa$\mathrm{gcm}$ destes imigrantes pelo albergue, o número também é expressivo, $34,1 \%$ do total geral.

Foto. Sidney A. da Silva

de mulheres; a distribuição das faixas etárias, com um ligeiro aumento dos que se enquadram na faixa dos 45 a 54 anos de idade $(17,9 \%)$, as atividades ocupacionais e a escolaridade. Porém, os dados apontam para algumas especificidades, como o alto percentual de pessoas que passaram pelo albergue, $42,1 \%$ dos 171 registros consultados, situação esta que se repete também entre os uruguaios. Outro dado que aparece pela primeira vez nos grupos analisados até agora, é a condição de uma parte desses imigrantes em relação ao seu estado civil, ou seja, a condição de divorciado, atingindo $9,0 \%$ do total.

No que diz respeito à origem destes imigrantes, grande parte apontou Buenos Aires, seguida por Córdoba, Rosário, Mar del Plata e Santa Fé. O nível escolar médio indica que grande parte completou o segundo grau e uma parte menor o nível superior. As ocupações mais recorrentes são o artesanato, o magistério, os serviços. como técnico em eletrônica, mecânica, pintura, carpintaria, serviços em restaurantes, cabeleireiros, músicos, artistas e profissionais liberais como engenheiros, médicos e outros. Os locais de residência mais recorrentes são os bairros centrais e outros como Itaim, Santo Amaro, Penha, Tatuapé, Itaquera, Saúde, Aclimação e municípios vizinhos como o Embú, Itapecirica da Serra, São Bernardo, Suzano entre outros. A recorrência de um filho brasileiro é pequena, $10,5 \%$ do total de registros, bem como o número de pessoas casadas com brasileiros(as), 4,5\% dos casos.

\section{Uruguaios}

Entre os uruguaios a variação que pode ser ressaltada com maior evidência é a distribuição das faixas etárias. uma vez que sugere uma população de imigrantes mais envelhecida, sobretudo na faixa que compreende entre os 45 e 54 anos de idade, ou seja, $25,0 \%$. Nos demais itens há uma certa equivalência entre os dados apresentados sobre o Chile, seja no que se refere à composição por sexo, apresentando um percentual de $69,0 \%$ de homens e $31,0 \%$ de mulheres, seja em relação ao filho brasileiro, atingindo $20,6 \%$ dos 126 registros consultados, seja em relação ao estado civil, com uma predominância dos solteiros $(50,4 \%)$ sobre os casados $(29,9 \%)$, situação próxima àquela dos argentinos, bem como ao número de pessoas casadas com brasileiros(as), totalizando 5,6\%

Em relação ao item origem, grande parte dos mesmos apontou a Capital do país, Montevidéu, como ponto de partida, seguida por Rivera, Salto, Ijuí, Artigas e

\section{OS \\ HISPANO-AMERICANOS E O MERCADO DE TRABALHO}

Os dados explicitados acima nos revelam que a inserção dos hispano-americanos no mercado de trabalho paulistano se dá de forma diferenciada, embora no caso dos bolivianos e dos paraguaios esses grupos tenham pontos em comum, como é a forma de contratação e de trabalho nas pequenas confecções da cidade. Porém, mesmo neste caso específico, as relações de trabalho adquirem especificidades $\mathrm{cm}$ cada grupo, tornando, assim, perigoso fazer qualquer tipo de generalização.

É bom lembrar, entretanto, que a dinâmica de reprodução sócio-econômica das pequenas confecções nivela a todos, empregados e empregadores numa relação de subordinação à lógica de reprodução do capital, cada vez mais globalizado. Se por um lado a ausência de regras formais para reger as relações de trabalho nas pequenas confecções enseja toda e qualquer forma de exploração desta mão-de-obra, por outro, verifica-se que as formas de se resolver os conflitos entre patrões c emprega 
dos são diferenciadas de um grupo para outro.

Nesse sentido, os registros que consultamos trazem no seu verso relatos de vários conflitos entre empregados e empregadores, sobretudo entre os bolivianos. Constata-se com muita frequência casos de oficinistas que trazem seus compatriotas para trabalhar nas suas oficinas sem lhes pagar nada, depois de meses e até de anos de trabalho. Tudo o que o costureiro produz é anotado num caderno do patrão, ao qual o empregado não tem acesso. Desta forma. o oficinista investe o dinheiro de seus empregados em novas máquinas, aumentando sempre mais o seu empreendimento, ou até mesmo na construção da sua própria casa. Porém, na hora do acerto de contas, eles afirmam não ter o dinheiro para fazê-lo, aprofundando, assim, a dependência dos empregados em relação aos seus empregadores.

Entre os paraguaios, entretanto, não foi constatado nenhum caso semelhante, o que nos possibilita levantar a hipótese de que as relações de trabalho entre eles sejam regidas por outros critérios, ou ainda, que estes trabalhadores se utilizem de outras instâncias para resolver os seus conflitos de trabalho, não necessitando da intermediação da Pastoral. Importa sinalizar, entretanto, ainda um outro aspecto que me parece revelador, ou seja, a coesão do grupo propiciada por uma cultura e língua comuns, o guarani. Talvez este elemento mereceria uma maior atenção em nossa análise, o que não é possível fazê-lo no âmbito deste trabalho.

A complexidade das relações de trabalho entre estes imigrantes pode ser ainda explicitada através de um fato recente, ou seja, com a aprovação da lei de anistia no dia 29 de junho de $1998^{1}$, surgiu uma grande preocupação entre os oficinistas em relação a um possível movimento reivindicatório de direitos trabalhistas por parte dos costureiros, pois a partir da legalização dos mesmos os patrões deveriam registrar as suas carteiras de trabalho, pagando-lhes todos os direitos contemplados na CLT, inclusive os retroativos. Porém, vale ressaltar a prolongada crise pela qual passa o setor da confecção, em que os preços pagos por peça ao oficinista caíram consideravelmente nos últimos dois anos, tornando, assim, ainda mais perversa a relação entre capital e trabalho neste setor do mercado de trabalho. Nesse sentido, pode-se dizer que a regularização destes trabalhadores não mudará substancialmente a qualidade de vida dos mesmos, pois terão que ajustar-se às leis do mercado se quiserem continuar trabalhando neste tipo de atividade. Frente a esta possibilidade uma costureira afirmou categoricamente que "é melhor trabalhar sem a carteira registrada do que perder o emprego". Outros manifestaram, porém, o desejo de conseguir um outro emprego, de acordo com as profissões exercidas no país de origem

Pode-se dizer, contudo, que mesmo a despeito dos baixos preços pagos por peça aos costureiros e a não concessão de direitos já garantidos pela CLT, o que se observa, na verdade, é que este mercado de mãode-obra continua dinâmico e atraindo novos costureiros. Porém. com uma diferença: as exigências para a contratação aumentaram. Uma delas é ter experiência neste tipo de atividade. Num domingo que passei pela praça do Pari, um coreano distribuía pequenos anúncios de trabalho dizendo: "Se necesita costureros con mucha práctica"

Tal exigência sinaliza as transformações pelas quais passa o mercado de trabalho global, as quais afetam de igual forma as pequenas confecções. tidas até então como "artesanais". Se por um lado se exige dos trabalhadores uma certa especialização para atender as exigências dos empregadores, o mesmo pode-se dizer destes últimos, que precisam recorrer aos avanços tecnológicos para responder às exigências de um mercado cada vez mais competitivo, o qual exige qualidade com custos cada vez mais ínfimos.

Se para os costureiros(as) a questão central é preservar o emprego a despeito da superexploração que se faz de sua mãode-obra, para os outros imigrantes mais qualificados, como é o caso dos chilenos, uruguaios e argentinos, o problema atual é onde encontrar um emprego de acordo com sua qualificação profissional. Os registros apontaram para a tendência de um crescente desemprego e empobrecimento de imigrantes que anteriormente exerciam as suas profissões, sendo agora obrigados a sujeitar-se a qualquer tipo de trabalho. $\mathrm{O}$ trabalho autônomo em algum ramo do comércio ambulante, dos serviços como trabalhar em restaurantes ou dar aulas de espanhol, pode ser uma saída para muitos. Outra opção é abrir uma oficina de costura, setor este onde havia uma certa predominância de bolivianos e paraguaios, e que agora já é possível encontrar também chilenos.

Animados pelas notícias positivas de seus países de origem, outros buscam no retorno uma forma de reconstruírem as suas esperanças num futuro melhor, como é o caso dos chilenos e paraguaios. No entanto, ao retornarem encontram ura país trans. formado e com poucas opções de inserção no mercado de trabalho. Além disso devem enfrentar o problema da adaptação de seus filhos brasileiros numa outra cultura, o que em alguns casos acaba por inviabilizar tal possibilidade.

$\mathrm{O}$ alto índice da passagem de argentinos e uruguaios pelo albergue que acolhe os migrantes na cidade de São Paulo, a AVIM, é um indicador do empobrecimento pelo qual vem passando estes imigrantes, cujo processo, na verdade, iniciou-se em seus países de origem e se aprofundou no país de destino. O caso de um uruguaio que perdeu todos os bens em razão do pro. longado desemprego e recorreu sete vezes à Pastoral do Migrante em busca de ajuda para pagar o aluguel e buscar um emprego, é um exemplo cabal de tal processo. Por outro lado pode estar indicando também a fragilidade das redes sociais no interior da comunidade, cujo fenômeno deve ser analisado também a partir de uma clivagem de classe.

Outro fato sinalizador desta realidade é a circularidade dos mesmos entre as grandes cidades brasileiras, particularmente entre as capitais, em busca de trabalho. A circularidade da mão-de-obra seja ela qualificada ou não, apresenta-se, portanto, como uma tendência, particularmente para as migrações não-documentadas, pois trata-se em primeiro lugar de uma estratégia de reprodução ampliada do capital, e em segundo, de um grande negócio para os grupos envolvidos neste "tráfico de mãode-obra" (Hugo, 1998:9; Silva, 1998:27). Nesse sentido, observa-se que as trajetórias dos imigrantes hispano-americanos que 
trabalham no ramo da costura se pautam cada vez mais pela instabilidade, propiciada por um mercado de trabalho cada vez mais competitivo e sujeito aos altos e baixos da economia global.

\section{OS \\ HISPANO-AMERICANOS E O PROCESSO DE SUA INTEGRAC̣ÃO SÓCIO-CULTURAL}

Em um mundo cada vez mais globalizado a questão da integração dos migrantes ganha uma certa relevância, isto porque uma maior circularidade de pessoas pelo planeta coloca-as numa situação de mútuo estranhamento, explicitando, por um lado, e remarcando, por outro, as diferenças étnico-culturais de cada grupo.

Em São Paulo a presença hispano-americana tornou-se expressiva nos últimos anos, e, portanto, é impossível que a mesma passe despercebida, mas ao contrário, novos espaços vêm sendo conquistados por estes imigrantes, seja em termos de mobilidade social, de expressão cultural e de participação política ${ }^{2}$.

Vale lembrar, entretanto, que a questão da integração dos imigrantes hispanoamericanos coloca-se de maneira diferenciada, pois a conjugação de vários fatores contribuem para que a inserção de cada grupo apresente características próprias. Entre estes fatores destacamos a posição econômica e política que cada país ocupa em relação ao Brasil, bem como fatores de ordem étnica e cultural. Isto significa que para os imigrantes menos qualificados, oriundos de países mais pobres em relação ao Brasil e com um alto percentual de pessoas com ascendência indigena, a sua socialização se dá de forma igualmente perversa como aquela oferecida aos migrantes internos, particularmente aos nordestinos. Isto significa que a luta pela sobrevivência se coloca de forma igualmente exigente para todos. Porém, para os imigrantes mais pobres, como é o caso dos bolivianos, paraguaios e peruanos, esta socialização apresenta um agravante a mais, ou seja, além das barreiras de ordem legal, expressa na dificuldade para docu- mentarem-se, pesa sobre eles também vários estigmas, tornando ainda mais desiguais e desafiadoras as suas trajetórias na cidade.

Em outros contextos, como o europeu, o que se observa é a transformação de um problema econômico em um problema racial, pois a categoria de "etnia" tende a ser recoberta pela de "raça". Nesse sentido, os migrantes passam a ser responsabilizados pelos problemas sociais, tais como o desemprego, a alta dos preços, a violência, a prostituição, o tráfico de drogas, entre outros. Um exemplo emblemático dessa realidade são os estigmas atribuídos aos bolivianos em São Paulo, os quais são vistos pelo senso comum e pela mídia como possíveis "traficantes", gente de "pouca cultura", de origem indígena e de pele morena (Silva, 1997: 185-192). Da mesma forma os paraguaios são vistos como "muambeiros", e os peruanos como "pessoas que se dedicam ao furto".

Assim sendo, no Brasil as desigualdades sociais tendem a tornar cada vez mais explícitas as diferenças de ordem étnica e cultural, transformando-as em estigmas ${ }^{3}$. No entanto, a questão central que se apresenta igualmente desafiadora para todos é como garantir o exercício da cidadania , uma vez que, a maioria dos brasileiros não tem os seus mínimos direitos garantidos pelo Estado, como o direito à moradia, à saúde, à educação, ao seguro desemprego, entre outros. Temos, na verdade, uma situação de "cidadania regulada", onde o que prevalece são as relações de favor e de apadrinhamento, que são estabelecidas entre grupos dominantes e populações empobrecidas.

Num contexto de integração de blocos econômicos, como é o caso do Mercosul, cabe indagar sobre os possiveis desdobramentos que a questão dos direitos dos imigrantes tomará neste espaço político ampliado. Na verdade as fronteiras geográficas e políticas deveriam "desaparecer" para dar lugar a uma maior circulação não só de mercadorias, como sugere o próprio nome do tratado, mas também de oportunidades e bens culturais para toda a população. No contexto europcu, a admissão de uma "cidadania européia", expressa num passaporte comum a todos, parece caminhar nesta direção. No entanto, sempre é complicado falar em equiparação de direitos envolvendo nações com diferenças tão acentuadas, como é o caso das que conformam o Mercosul. sobretudo na atual conjuntura em que se fala na "flexibilização" das leis trabalhistas, com a perda de direitos adquiridos.

Para Gustavo Lins Ribeiro, porém, já seria possivel pensar numa "cidadania transnacional", alargando assim o conceito de Estado Nação, o qual não estaria mais limitado a um território especifico. Ao analisar o caso dos imigrantes brasileiros em São Francisco(USA), o autor constatou que o crescente número de brasileiros no exterior e o volume de remessas enviadas anualmente ao Brasil, provocou o governo brasileiro a tomar algumas iniciativas. Entre elas, destaca-se a possibilidade do emigrante participar no processo político do seu país através do voto, a oferta de vários serviços de apoio, como a elaboração de "cartilhas" de orientação ao imigrante brasileiro, fornecidas pelos Consulados localizados nos lugares onde eles residem. Vale ressaltar que tais cartilhas foram sugeridas pelos Conselhos de Cidadãos, instituídos pelos referidos Consulados (Ribeiro, 1998:17-18)

A proposta de Ribeiro apresenta-se, portanto, auspiciosa, uma vez que a preocupação do governo brasileiro com os seus cidadãos no exterior, exigindo do país receptor um melhor tratamento aos seus emigrados, abre a possibilidade de se exigir do mesmo um tratamento recíproco também para os imigrantes residentes no Brasil. Nesse sentido, a sensibilidade e a discussão de tais direitos deverão se fazer cada vez mais presentes nas agendas dos encontros internacionais, transformandose em acordos multilaterais ou bilaterais. E para que isto deixe de ser apenas uma hipótese, a pressão dos grupos de imigrantes e das organizações não governamentais (ONGs) assume um papel fundamental.

Em primeiro lugar. é preciso admitir que o potencial de organização está presente em todos os grupos de migrantes, porém, de forma diferenciada. Pois, é preciso considerar os vários fatores históricos presentes no processo de sua inserção $\mathrm{em}$ um determinado contexto social. Em segundo lugar, é notória a diferença entre 
a inserção de um grupo de imigrantes oriundos de países que ocupam uma posição subalterna ao país receptor, como é o caso dos bolivianos, paraguaios e peruanos no Brasil. Ao contrário desses últimos, aqueles oriundos de países considerados "desenvolvidos", recebem um tratamento diferenciado, a começar pela sua entrada no país via aeroporto.

Vale ressaltar, no entanto, que o processo organizativo de cada grupo é mais ou menos efetivo de acordo com os problemas enfrentados pelos mesmos, e a partir dos interesses que o grupo passa a veicular em busca de uma maior ou menor visibilidade. Um Caso exemplar estudado por Silva (1998), mostrou que um grupo de imigrantes bolivianos só passou a se organizar para defender os seus interesses, a partir do momento em que a imprensa local começou a relacionar o grupo como um todo com a utilização de mão-de-obra "escrava", veiculando, assim, uma imagem extremamente negativa dos mesmos. Nesse sentido, a construção de uma nova identidade social tornou-se uma das questões centrais para o referido grupo.

Entre as formas adotadas por eles para propiciar este processo de recriação de indentidades estão a valorização das línguas originárias, como o quêchua, o aimará e o guarani, elementos do folclore, como as várias danças regionais, e, sobretudo. as festas devocionais, seja entre bolivianos, chilenos, paraguaios e peruanos. Nesse sentido, no mês de julho para os chilenos e agosto para os bolivianos, temos um ciclo de festas marianas realizadas no espaço da Pastoral do Migrante, em que vários elementos aferidores de identidades são veiculados por estes grupos com trajetórias diferenciadas.

Um exemplo disto é a grande expressividade que as festas bolivianas vêm ganhando nos últimos anos em São Paulo. Na Igreja N. Sra. da Paz são realizadas duas festas: a de N.Sra. de Copacabana (06 de agosto) e de N.Sra. de Urkupiña ( 15 de agosto), onde se reúnem cerca de mil pessoas em cada uma delas. Para cada festa é escolhido um "pasante" ou festeiro que se encarrega de preparar a festa, a partir de uma forma de organização própria (Silva, 1997:237).

Diferentemente das festas bolivianas, a festa chilena em louvor à Nossa Senhora do Carmo (16 de julho) é organizada por várias pessoas que participam da Pastoral, algumas, inclusive, desde o início da mesma. Esta festa começou a ganhar visibilidade, no entanto, a partir de 1996, quando apareceram também alguns conflitos, em razão da apresentação de algumas danças folclóricas, entre elas a "diablada", dança originária da região das minas da
Bolivia.

Segundo alguns bolivianos, os chilenos estariam se apropriando também do seu folclore, além de já ter se apropriado do seu litoral em 1879. No entanto, um chileno se justificou publicamente dizendo que "o folclore não tem fronteiras", e que "o importante é a união dos povos".

Os paraguaios, por seu turno, também celebram a festa da sua padroeira N.Sra.

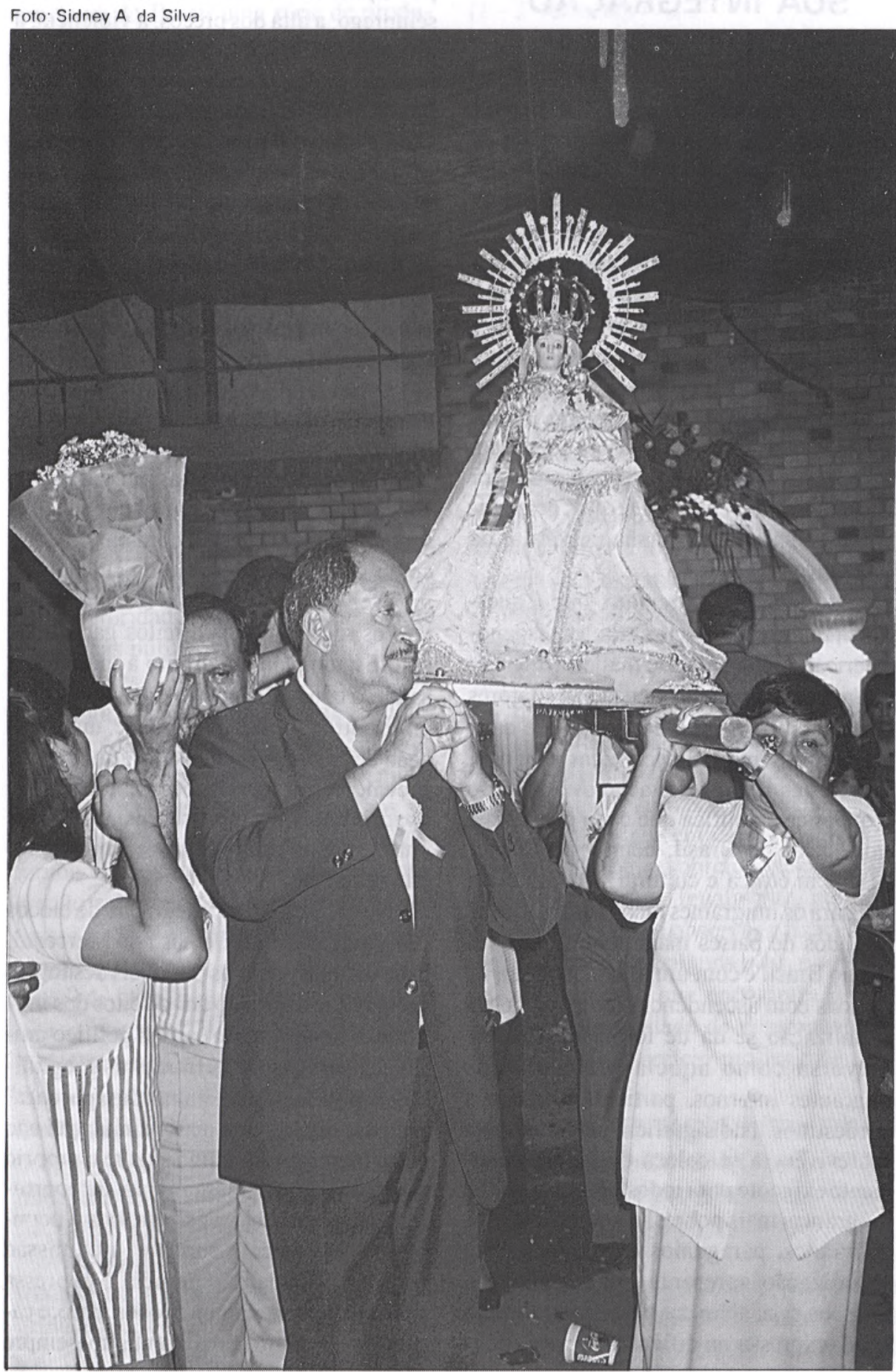


de Caacupê, no dia 08 de dezembro, porém, de forma mais modesta. Vale notar que esta festa, também realizada no espaço da Pastoral do Migrante, parece estar ganhando um novo impulso a partir de estratégias adotadas por outros grupos, como é o caso dos novenários em família

Se para os bolivianos, chilenos e paraguaios o espaço da Pastoral é um lugar de recriação cultural e de identidades, o mesmo não se dá com os peruanos, uruguaios e argentinos, cuja participação dos mesmos é mínima, e, em alguns momentos, inexistente. No caso peruano, este grupo se reúne pelo menos duas vezes por ano para celebrar as festas de seus santos(as), numa igreja cujo nome é o mesmo da sua padroeira, Santa Rosa de Lima. Esta festa é celebrada no dia 23 de agosto, quando se realiza também um festival de danças e comidas típicas envolvendo outros países. Porém, a festa mais concorrida pelos peruanos é a do Senhor dos Milagres, realizada no último sábado do mês de outubro. A não participação dos mesmos em eventos culturais e religiosos da Pastoral do Migrante poderia estar relacionada a duas hipóteses: a primeira se deve à desconfiança gerada por razões de ordem política atinentes aos problemas do país de origem. A Segunda poderia estar relacionada ao preconceito dos bolivianos em relação aos mesmos, pois, segundo alguns bolivianos, eles estariam se dedicando a atividades ilícitas em São Paulo, além de se fazerem passar por bolivianos, em razão das semelhanças físicas. Nesse sentido, os estereótipos construídos pelos brasileiros em relação aos peruanos, estariam sendo transferidos também aos bolivianos. Por outro lado, a não busca de visibilidade pode ser considerada também parte das estratégias de mobilidade construídas pelos imigrantes de forma individualista, como uma forma de autoproteção social dos estigmas que são atribuidos ao seu grupo pela sociedade local (Silva, 1997:194)

Já no caso argentino e uruguaio a não participação pode estar relacionada a questões de outra ordem, ou seja, de classe social e de orientação religiosa, em que os níveis de participação em sacramentos da Igreja Católica é baixo. Isto revela que estes grupos dispõem de outros espaços de sociabilidade na cidade, como bares, res- taurantes e clubes, como é o caso do "Rancho Uruguayo", localizado na zona sul da cidade. No entanto, tais grupos começam a valorizar um espaço de manifestação cultural criado pela Pastoral do Migrante em 1989, denominado então de "Show Latino-americano", e que a partir de 1998 passou a ser denominado de "Festa Internacional das Nações", uma vez que vários paises, além dos hispano-americanos, passaram a participar de tal evento. A ampliação de tal espaço expressa na verdade, por um lado, a proposta universalizadora da Igreja Católica, e, por outro, a sua preocupação com as especificidades culturais, pois é nesse campo que está em jogo a sua complexa proposta da "inculturação"4. Para os imigrantes, entretanto, os seus interesses estão voltados mais para a reafirmação de suas diferenças, do que para a sua diluição, tornando-as, assim, em traços diacríticos das várias identidades em jogo.

\section{CONCLUSÃO}

Ao finalizar este trabalho sobre os hispano-americanos em São Paulo, os dados aqui analisados nos sugerem algumas conclusões preliminares, as quais mereceriam um aprofundamento posterior, em razão dos poucos trabalhos existentes sobre o tema.

Entre as várias questões que nos foi possível auferir nos dados analisados, destacamos uma tendência presente nos vários fluxos migratórios na América Latina, qual seja, a da migração dos grandes centros urbanos, em geral a capital dos respectivos países, para outros centros latino-americanos, como é o caso de São Paulo, Buenos Aires, Santiago do Chile, entre outros. Isto supõe um processo migratório dentro do próprio país, seja rural-urbano ou urbano-urbano. E para que estes fluxos possam se manter, vale destacar o papel das redes sociais, cuja interligação entre os que partiram e os que ficaram constituise num elemento vital para a continuidade de tais fluxos, bem como para a construção de estratégias de mobilidade social e de reconstrução de identidades no país de destino

Em sendo assim, os dados nos revelaram que entre alguns grupos analisados neste trabalho, como são os casos dos ar- gentinos, uruguaios e peruanos, tais redes podem ser menos acionadas pelos imigrantes, dcixando-os desprotegidos numa grande cidade como São Paulo. O alto número dos que passaram pelo albergue em cada grupo, $42,1 \% ; 34,1 \%$ e $26,7 \%$ respectivamente, poderia confirmar tal afirmação.

Nesse sentido, vale destacar o papel das igrejas no processo de inserção dos (i)migrantes no meio urbano, sobretudo no que diz respeito à organização, à recriação de identidades e à defesa de direitos fundamentais dos mesmos. A Pastoral dos Latino-americanos em São Paulo é, portanto, um exemplo disto, a qual desde o período da repressão política constitui-se num espaço de encontro, de orientação jurídica e de organização dos imigrantes, inicialmente como foi o caso dos chilenos e outros. Atualmente, este espaço é amplamente disputado por vários grupos, pois o mesmo passou a ser uma espécie de "vitrine" através da qual cada grupo procura reapresentar e remarcar as suas diferenças culturais em alguns eventos, como é o caso da "Festa Internacional das Nações". Para ilustrar esta realidade, vale citar a fala de um boliviano diretor de um grupo folclórico, o qual argumentou que a Pastoral "é um outro Memorial da América Latina em São Paulo".

O espaço aberto aos (i)migrantes pelas igrejas, além de revelar o interesse das mesmas em difundir os seus projetos evangelizadores, pode estar sinalizando, portanto, o quão problemática é a inserção dos (i)migrantes num contexto sóciocultural diverso e adverso. Os elevados índices de pessoas que optaram por ter mais um filho no Brasil ou por um matrimônio com cônjuges brasileiros, como é o caso dos paraguaios, parecem ser reveladores na medida em que indicam as dificuldades de se enquadrar dentro das leis do país receptor, ou ainda, podem estar indicando uma tendência exogâmica dentro do grupo.

Poderíamos apresentar, ainda, como perspectivas para os vários grupos analisados as seguintes possibilidades. Em primeiro lugar, em se fortalecendo o processo de integração regional, poderíamos apontar como uma tendência o aumento da circularidade de pessoas qualificadas sem nenhuma restrição entre os países envol- 
vidos em tal processo. Entretanto, o mesmo não se daria com os bolivianos, que participam na condição de associados e dos peruanos, que não participam de tal processo, os quais continuariam emigrando para o Brasil e enfrentando o problema da indocumentação, uma vez que grande parte deles se enquadra no perfil de uma mãode-obra pouco qualificada e se direciona para setores específicos do mercado de trabalho. No caso peruano, vale ressaltar ainda que estes além de se concentrarem na região Sudeste, estariam se concentrando também ao Norte do país. Com relação aos paraguaios e, particularmente, chilenos, temos uma certa estagnação e, poderíamos até dizer, diminuição do fluxo, pois o retorno ao país de origem tem sido uma opção cogitada por vários deles. No entanto, a reemigração tem sido também observada em muitos casos, especialmente entre os que trabalham no ramo da costura, por se tratar de um setor onde a oferta de trabalho se dá com maior intensidade em alguns períodos do ano e depende das oscilações do mercado.

Outra possível tendência é o aumento da presença de mulheres nos fluxos migratórios, a possibilidade de mais pessoas optarem pela formação de uma família em São Paulo, seja com parceiros(as) do mesmo grupo de conacionais ou com brasileiros(as), pois para a maioria dos jovens o retorno ao país de origem só seria visualizado na medida em que fosse possível retornar com algum capital e iniciar o seu próprio negócio. No entanto, as possibilidades de mobilidade social e econômica parecem ser melhor visualizadas em São Paulo, em razão das oportunidades oferecidas pelo mercado, e, na medida que conseguirem combinar trabalho familiar $\mathrm{e}$ a contratação de mão-de-obra dos próprios compatriotas.

A precarização das relações de trabalho parece ser outra tendência, seja por razões exteriores ao contexto local, ditadas pelo processo de reprodução do capital em nível global, seja por outras questões conjunturais, como a falta de documentos, seja pelo caráter étnico-cultural que tais relações podem adquirir, contribuindo, desta forma, para aprofundar ainda mais os níveis de exploração da força de trabalho, como é o caso das pequenas confecções.

Não obstante o cenário desalentador para os (i)migrantes mais pobres, em razão de um maior controle das fronteiras, das exíguas ofertas de empregos e da sua precarização, do crescente preconceito em alguns países da região, numa tentativa de responsabilizá-los pelos problemas econômicos atuais, vale lembrar, no entanto, que a integração dos povos antecede e extrapola os tratados oficiais, pois os mesmos não dão conta de captar as especificidades e contradições inerentes em tais processos.

* Sidney Antonio da Silva é antropólogo e Diretor do CEM.

\section{NOTAS}

1. O governo brasileiro concedeu três anistias a partir dos anos 80, uma em 1981, outra em 1988, e a última, lei 9.675 de 29 de junho de 1998. Vale notar que o número de pessoas que se beneficiaram dessa anistia pode ser considerado muito aquém do montante alcançado pela anistia anterior. Em 1988, foram 30 mil imigrantes e em 1998, 39.131 mil (SREI DPMAF). Vários fatores podem ter contribuido para isto, sobretudo entre os bolivianos. Entre eles destacamos o custo da documentação (R\$ 120,00 por pessoa), bem como a falta de recursos para fazêlo, em razão do não pagamento dos empregados; a não permissão dos empregadores para que seus empregados fornecessem o endereço de sua oficina de costura, temendo uma fiscalização posterior; a perspectiva de uma possivel volta a curto prazo ao pais de origem; o medo de se apresentarem à Policia Federal, particularmente entre aqueles que foram autuados pela mesma anteriormente, e, finalmente, no caso dos menores de idade, a morosidade do processo de concessão da guarda provisória pela Justiça.

2. Nas eleições de 1998 , havia um paraguaio naturalizado brasileiro candidato à deputado estadual pelo Estado de São Paulo.

3. Pode-se dizer que existe no Brasil uma intolerância latente em relação aos estrangeiros, a qual pode tornar-se mais ou menos explícita, de acordo com a conjuntura. O crescente desemprego enfrentado pela sociedade brasileira passou a ser justificativa para tal atitude. A declaração do apresentador do telejornal da Record sobre a concessão da lei de anistia aos estrangeiros, é um exemplo disto. Para ele, é um absurdo o governo brasileiro anistiar estrangeiros indocumentados num momento de acentuado desemprego, pois estes estariam "roubando" os empregos dos brasileiros.

4. Tal proposta insere-se dentro da preocupação da Igreja Católica em traduzir a mensagem do Evangelho nas culturas particulares. No entanto, este conceito apresenta várias implicações de ordem teórica, na medida em que procura preservar ao mesmo tempo o universal e o particular, o idêntico e a diversidade, temendo, porém, a dissolução da mensagem. Cf. Paula Monteiro, "A universalidade da Missão e a particularidade das culturas" In:
Entre o Mito e a História: o V centenário do descobrimento da América. Paula Monteiro(Coord.) Petrópolis, Vozes, 1996, pp.31-135

\section{BIBLIOGRAFIA}

APPADURAI, Arjun

(1997) "Soberania sem Territorialidade: notas para uma geografia pós-nacional". In: Novos Estudos CEBRAP, n० 49, novembro, pp.36-46.

BAPTISTA, Dulce M. T.

(1998) Nas Terras do "Deus Dará"- Nordestinos e suas redes sociais em São Paulo. Tese de Doutoramento em Ciências Sociais. Săo Paulo, PUC. (mimeo)

BEVILAQUA, Maria Edith G. O.

(1992) Estrangeiros: Peregrinos da América. Os Latino-americanos do Cone Sul (argentinos, chilenos e uruguaios) no Brasil de São Paulo (São Paulo e Campinas) 1970-1990. Dissertação de Mestrado em Antropologia Social, Unicamp. (mimeo)

GRAEME, Hugo

(1998) "Migrações Internacionais năodocumentadas: uma tendência global crescente". Travessia-Revista do Migrante, $\mathrm{n}^{\circ} 30$, janeiroabril, pp. 5-12.

KOLTAI, Caterina (org)

(1998) O estrangeiro. São Paulo, Escuta/ FAPESP.

LODIGIANI, R. Zandrini, S

(1995) "Il caso Peruviano" In: L'integrazione Subalterna: Peruviani, Eritrei e Filippini nel mercato del lavoro milanese. Quaderni I.S.MU, Milano, 3/ pp. 24-42.

MÁRMORA, Lelio

(1997) Las Politicas de Migraciones Internacionales. Buenos Aires, Alianza.

RIBEIRO, Gustavo Lins (1998) "Goiânia, Califórnia. Vulnerabilidade, ambiguidade e cidadania Transnacional". In Série Antropológica, 235, UnB, Brasilia.

SALES, Teresa

(1998) "Brasil - Massachusetts- Cenas de um processo migratório". In: O Fenômeno Migratório no Limiar do $3^{\circ}$ Milênio. Desafios Pastorais. São Paulo, Vozes, 1998, pp.55-67.

SILVA, Sidney A. da

(1997) Costurando Sonhos. Trajetória de um grupo de imigrantes bolivianos em São Paulo. São Paulo, Ed. Paulinas

SILVA, Sidney A. da

(1998) "Clandestinidade e Intolerância. O Caso dos bolivianos em São Paulo". In: TravessiaRevista do Migrante, $\mathrm{n}^{\circ} 30$, janeiro/abril, pp. 25 . 29.

SPRANDEL, Marcia A.

(1998) "Brasileiros do além-fronteira: Paraguai" In O Fenômeno Migratório no Limiar do Terceiro Milênio: Desafios Pastorais. São Paulo, Vozes, pp.113-138.

VAINER, Carlos B

(1996) "A Violência como fator Migratório: silêncios teóricos e evidências históricas". In Travessia-Revista do Migrante, $n^{\circ} 25$, maio/ agosto, pp.5-9.

V.AA

(1991) "Hispano-americanos, os presentes ausentes".In: TRAVESSIA-Revista do Migrante, $n^{0} 11$, Setembro/Dezembro, pp.37-40. 